\title{
Uncommon genetic syndromes and narrative production - Case Studies with Williams, Smith-Magenis and Prader- Willi Syndromes?
}

Elena Garayzábal-Heinze ${ }^{1}$, Magdalena Capó ${ }^{1}$, Esther Moruno ${ }^{1}$, Óscar F Gonçalves ${ }^{2}$, Montserrat Férnandez ${ }^{3}$, María Lens ${ }^{4}$ and Adriana Sampaio ${ }^{2}$

${ }^{1}$ Department of Linguistics, University Autónoma of Madrid, 28049 Madrid, Spain, ${ }^{2}$ Neuropsychophysiology Lab, CIPsi, School of Psychology, University of Minho, Braga, Portugal, ${ }^{3}$ Genetic Molecular Unit, Galician Public Foundation of Genomic Medicine, University of Santiago de Compostela, Spain, ${ }^{4}$ Nursing Department, University of Santiago de Compostela, Spain

This study compares narrative production among three syndromes with genetic microdeletions: Williams syndrome (WS), Smith-Magenis syndrome (SMS), and Prader-Willi syndrome (PWS), characterized by intellectual disabilities and relatively spared language abilities. Our objective is to study the quality of narrative production in the context of a common intellectual disability. To elicit a narrative production, the task Frog! Where Are You was used. Then, structure, process, and content of the narrative process were analysed in the three genetic disorders: WS $(n=2), \operatorname{SMS}(n=2)$, and PWS $(n=2)$. Data show evidence of an overall low narrative quality in these syndromes, despite a high variability within different measures of narrative production. Results support the hypothesis that narrative is a highly complex cognitive process and that, in a context of intellectual disability, there is no evidence of particular 'hypernarrativity' in these syndromes.

KEYWORDS Williams syndrome, Smith-Magenis syndrome, Prader-Willi syndrome, Narrative abilities 


\section{Introduction}

Narrative production is a highly multifactorial skill, embedded within the context of the discourse. Its production depends on a complex network of cognitive, affective, and social processes. Indeed, the production of a narrative implies: (I) an organization of experience into a coherent sequence; $(2)$ the attribution of meaning to the events linking them to previous and later information; $(3)$ taking into an account the main topic and principal events for reproducing them effectively; (4) the use of interpersonal language resources, adjusting the structure to content in order to keep the attention and the interest of the interlocutor; (5) an understanding of the cognitive processes, namely, the ability to generate inference, to establish cause-effect relationships and to give relevant information; (6) connexion of new with old information; (7) recognition of interlocutor's importance; (8) organization of the plot; and (9) organization of the elements of the language system. Indeed, given its multimodal and integrative nature (Gonçalves et al., 2004) narrative production may be an important tool to study the cognitive, affective, and social aspects of language in normal and atypical neurodevelopment (Reilly et al., 2004). Thus, studying narrative production in abnormal development, where intellectual disability coexists with relatively spared language production, such as in Williams syndrome (WS), Smith-Magenis syndrome (SMS), and Prader-Willi syndrome (PWS), could elucidate about the genetic contributions to language and narrative organization in atypical neurodevelopmental genetically based disorders.

However, if there are few studies addressing intersyndromic general comparisons, even less are available for the study of rare genetically based syndromes (Artigas-Pallarés, 2002; Feinstein and Singh, 2007; Annaz et al., 2009). Moreover, the existing studies were characterized by comparisons between low-frequency rare genetic syndromes and high-frequency diseases such as Down syndrome, fragile X or autism, or even specific language disorder. Finally, the majority of these intersyndromic comparison studies have been focused on medical and genetic characterization, with only a small number of them addressing psychological aspects, and none focusing on the linguistics and narrative profiles of the disorder.

WS is a neurodevelopmental disorder, with a prevalence of I/7500 (Stromme et al., 2002), characterized by a submicroscopic deletion on chromosome 7 qI I.23 (Bellugi et al., I999). Their typical physical characteristics include facial dismorphology (elfin-like face, depressed nasal bridge, stellate iris pattern, flared nostrils, wide mouth with prominent lips and irregular dentition) and a specific clinical phenotype (which includes cardiovascular defects, calcium metabolism abnormalities, hypertension, failure to thrive in infancy, and delayed development). Also, they usually exhibit poor motor coordinations, muscle tone disorders (hypertonia), hyperacusia, and articulation problems (Bellugi et al., I990, I999, 2000; Mercuri et al., I997; Metcalfe, I999; Gagliardi et al., 2003; Chiang et al., 2007).

WS individuals display also distinct behavioural patterns, characterized by an excessive social behaviour, with a strong impulse towards social contact and affective expression (Bellugi et al., I999; Jones et al., 2000). However, they may evidence some maladaptive behaviours such as hyperactivity, propensity towards inattention, and even social withdrawal, interfering significantly with their normal 
daily living (Greer et al., I997). Individuals with WS also present a unique cognitive phenotype, with a mild-to-moderate intellectual disability (mean IQ: 55 , standard deviation: II, range: 40-90) and an uneven pattern of cognitive performance. Specially striking is a dissociation found between severely impaired visuospatial cognition and relatively preserved face processing and linguistic abilities (Bellugi et al., I994, 2000).

Indeed, several studies show evidence for a proficient and creative use of specific aspects of expressive language as well as highly prolix vocabulary production of typical and atypical words (Bellugi et al., I994). However, this notion of spared language abilities was further challenged and subsequent studies demonstrated that linguistic function in WS is not only delayed in acquisition, but also impaired in adolescence/adulthood (Stevens and Karmiloff-Smith, I997; Semel and Rosner, 2003; Thomas et al., 2006). Indeed, abnormal grammatical (syntactic and morphosyntactic), lexico-semantic, and pragmatic processes (production of a 'cocktail party speech', discourse incoherence, stereotyped conversation, and difficulties at initiating and developing conversational rapport) were also found in this syndrome (Gonçalves et al., 2004; Stojanovik, 2006; Brock, 2007; Garayzabal Heinze et al., 2007). In terms of narrative production, although it has been claimed that WS was a model of 'hypernarrativity' (Bellugi et al., I990; Semel and Rosner, 2003), the only consistent result found in these patients was the use of social hookers as evaluation devices for enriching the narrative and engaging the audience (Jones et al., 2000; Gonçalves et al., 2004; Reilly et al., 2004; Garayzabal Heinze et al., 2007).

Another microdeletion syndrome that is associated with a specific social and language phenotype is SMS (Smith et al., I986). This is a rare disease ( $\mathrm{I}$ in about I 5 000-25 000) caused by a microdeletion in chromosome I7pII·2 (Greenberg et al., I99I). Although the SMS has not yet been as widely described as WS, patients with this syndrome also have an unusual phenotype, which includes a distinctive profile of physical, medical, and neuropsychological characteristics. Their typical physical characteristics include a specific facial phenotype (flattened mid-face, down-turned mouth, prominent cheeks and jaw, and synophrys), short fingers and toes, and flat feet. The clinical phenotype is associated with an inverted circadian rhythm of melatonin, which may cause sleep disturbances (Greenberg et al., I99I; Potocki et al., 2000). In addition, they also show hearing impairment, eye problems, hypercholesterolemia, hypertriglyceridemia, and thyroid function abnormalities. They usually have poor motor coordination (distinct, broad-based gait as walking pattern) and low muscle tone (Elsea and Girirajan, 2008). SMS individuals display also distinct behavioural patterns, which include hyperactivity, impulsivity, attention seeking, attention problems, sudden mood swings, explosive outbursts, prolonged tantrums, aggressiveness, and self-injury behaviours (Greenberg et al., I996; Dykens and Smith, I998). A very typical behavioural feature is self-hugging or rubbing hands together when excited. However, they show other positive behavioural patterns such as endearing and appealing personality, and a good sense of humour (Dykens and Smith, I998; Smith et al., I998; Sarimski, 2004; Gropman et al., 2006). The neuropsychological profile reveals a pattern of intellectual disability where relative weaknesses in sequential processing, short-term memory, and sensory integration, coexists with relative strengths in long-term memory 
specially for names, places, and events, perceptual closure, and relatively good discrimination figure/frame and space perception relation (Dykens et al., I997; Udwin et al., 200I). At early ages, they display good social abilities, which contrast with a marked language delay. At school ages, they tend to be extremely talkative and communicative, interrupting conversations, frequently asking the same questions and persevering in a topic.

PWS (Prader et al., I956) is another microdeletion genetic disorder associated with a distinctive cognitive and behavioural profile. This disorder is caused by a microdeletion in chromosome $\mathrm{I}_{5 \mathrm{qII}} \mathrm{I}_{3}$, occurring in about $70 \%$ of the patients. There can also be maternal disomy in $25 \%$ of the population with PWS, and $5 \%$ corresponding to an imprinting defect (Schulze et al., I997). The incidence of this syndrome is about I/I 5000 (Vogels et al., 2004; Vogels and Fryns, 2004). Most common physical features include facial characteristics (prominent nasal bridge, small hands and feet, soft skin, excess fat, high, narrow forehead, almond shaped eyes with thin, down-turned lips, light skin and hair) and medical features of hypothalamic dysfunction, hypotonic deficits in strength, coordination, balance, motor planning, strabismus, and diabetes (Donaldson et al., I994).

Behavioural common pattern includes insatiable appetite and frequent mood changes. During infancy, they are easy-going and loving, but as they grow, they can become rude with frequent outbursts, tantrums, aggressiveness, stubbornness, emotional lability, and obsessive-compulsive behaviours (Dykens et al., I999; Vogels et al., 2004). PWS individuals are intellectually disabled with an uneven cognitive profile of strengths and weaknesses. Problematic areas may include attention (Curfs et al., I99I; Wigren and Hansen, 2005), short-term auditory and visual memory, linear or temporal order sequencing, abstract thinking and cognitive rigidity with difficulties in adopting others points of view. Common strengths include long-term memory, reading ability, receptive language, good visuospatial abilities, and expressive vocabulary. In general, they tend to process more global than analytic concepts (Rosell-Raga, 2003). Language development is usually delayed in this syndrome as well (Kleppe et al., I990; Artigas-Pallarés, 2002; Lewis, 2006) and speech behaviour is characterized by being dysfluent (Defloor et al., 2000). Hypotonic problems lead to an unintelligible and slow speech, but when language is understandable, they give the impression of superior language abilities using resources such as clichés and elaborated linguistic structures, together with a wide vocabulary and loquacity that may shadow pragmatic and linguistic problems (Kleppe et al., I990; Akefeldt et al., I997; Lewis, 2006). They can be talkative, but with a tendency to perseverate on topics that limits the conversation.

In sum, these three genetic disorders are all characterized by microdeletions in different chromosomes with different phenotypic manifestations. However, in their phenotype, they all share intellectual disability, facial, and clinical conditions, a peak and valley cognitive architecture with relatively preserved language abilities, and a social phenotype that distinguishes them from other genetic neurodevelopmental disorders. Thus, since narrative production is dependent on a complex network of cognitive, affective, and social processes, we hypothesized that this dimension would also be impaired in the three syndromes mentioned above. Therefore, and because studies that characterize narrative profile are only 
reported in WS, the objective of the present report is to assess the commonalities and differences of the narrative production phenotype in six case studies of three microdeletion genetic syndromes.

\section{Method}

\section{Participants}

Six participants (males) diagnosed with three different genetic conditions (Table I) - WS, SMS, and PWS - participated in this study. Specifically, our sample included two participants with WS diagnosis (ages: I 3 years 3 months and I I years Io months), two participants with SMS diagnosis (ages: I2 years 7 months and Io years 3 months), and two participants with PWS diagnosis (ages: I 2 years 9 months and 13 years 9 months).

All individuals were previously confirmed with a positive fluorescent in situ hybridization and were recruited from the Spanish family associations. The Ethical Committee of the University Autonoma of Madrid approved the study and each participant's parent gave written informed consent for their participation in the study via consent forms, after a complete description of the study. Exclusion criteria consisted of sensorial or speech disorders, as well as co-morbidity with severe psychopathology not associated with the syndromes.

\section{Instruments}

\section{Wechsler Intelligence Scale for Children-Revised (Wechsler, 1974)}

This scale is one of the most used international systems in assessing intellectual quotient (full-scale IQ) allowing the discrimination of two intellectual levels related to verbal and non-verbal abilities (verbal IQ, VIQ; performance IQ, PIQ). In addition, it is an instrument that has been widely used in assessing mild and moderate intellectual disabilities.

\section{Peabody Picture Vocabulary Test (Dunn and Dunn, 1981)}

In order to assess receptive vocabulary abilities, the Peabody Picture Vocabulary Test (PPVT) was used. This instrument also allows the measurement of a VIQ and the discrimination of verbal mental age.

\section{Narrative elicitation task}

In this narrative task, individuals were presented with the 24-page wordless picture book, Frog, Where Are You? (Mayer, I969), and asked to tell the story to the TABLE 1

INFORMATION ABOUT THE PARTICIPANTS

\begin{tabular}{llllllll}
\hline Diagnosis & Case & Sex & Chronological age & Full-scale IQ & Verbal IQ & Performance IQ & PPVS \\
\hline Williams syndrome & Case MM & M & 11 years 10 months & 57 & 65 & 50 & $11^{\prime} 0$ \\
& Case CP & F & 13 years 3 months & 57 & 69 & 53 & $9^{\prime 3}$ \\
\multirow{2}{*}{ Sminth-Magenis syndrome } & Case SP & F & 10 years 3 months & 67 & 74 & 64 & $8^{\prime 2}$ \\
& Case MG & M & 12 years 7 months & 64 & 72 & 66 & $8^{\prime} 6$ \\
\multirow{2}{*}{ Prader-Willi syndrome } & Case AP & M & 12 years 9 months & 65 & 67 & 72 & $8^{\prime} 8$ \\
& Case IM & M & 13 years 9 months & 62 & 73 & 60 & $8^{\prime} 1$ \\
\hline
\end{tabular}


examiner. This storybook is about a boy and his dog, and their search for their missing pet frog. It is composed of 24 images with three main characters (the boy, the dog, and the missing frog) and consists of several main episodes with specific events (the boy's house - the boy and the dog look at the frog, that later runs away; the forest surroundings - where the boy and the dog call the frog; inside the forest - in which the boy and the dog look for the frog, while they meet a hamster, wasps, an owl, and a deer; and finally, the pond where they finally find the frog and its family.

Because it contains no words and given the multiplicity of processes, contents, and structural elements suggested by the images, this book provides a fairly rich context for language production and has been extensively used in several studies assessing linguistic skills across typically and atypically developing populations (Jones et al., 2000; Gonçalves et al., 2004; Reilly et al., 2004; Stojanovika et al., 2004). In addition to the series of temporally sequenced events, this task requires children to make inferences about characters' relationships, thoughts, feelings, and motivations throughout the story, thus integrating the local episodic elements within the more global search theme of the story. The children's narratives were videotaped, and further transcribed.

All narratives were analysed using three standard measures (each one with four subdimensions) and were coded according to Gonçalves's criteria (Gonçalves et al., 200Ia-c), using a Likert scale (Tables 2 and 3). This coding scheme is described elsewhere (Gonçalves et al., 20II; see also Appendix I) and was previously used with participants with WS and typically developing individuals (Henriques et al., 2004; Gonçalves et al., 2010, 201 I).

Structure and coherence (orientation, structural sequence, evaluative commitment, and integration), process and complexity [objectifying (sensorial complexity), emotional subjectifying (emotional complexity), cognitive subjectifying (cognitive complexity), and metaphorizing (metacognitive and meaning construction complexity], and finally, content and multiplicity (themes, events, scenarios, and characters) will be assessed. The coding and evaluation of these dimensions and subdimensions of narratives are described in the following manuals:

TABLE 2

SCORING CRITERIA USING LIKERT SCALES

\begin{tabular}{lllll}
\hline 1 & 2 & 3 & 4 & 5 \\
\hline Very Low & Low & Moderate & High & Very high \\
\hline
\end{tabular}

TABLE 3

\section{DIMENSIONS AND SUBDIMENSIONS OF NARRATIVE ASSESSMENT}

\begin{tabular}{lll}
\hline Structure and coherence & Process and complexity & Content and multiplicity \\
\hline Orientation & Objectifiying & Characters \\
Structural sequence & Emotional subjectifiying & Scenarios \\
Evaluative commitment & Cognitive subjectifiying & Events \\
Integration & Metaphorizing & Themes \\
\hline
\end{tabular}


- Manual for Evaluation of Narrative Structure and Coherence - this is a manual conceived to evaluate the degree of the structure and coherence of the narratives produced in the context of an oral speech (Gonçalves et al., $200 \mathrm{Ib})$. This model is based on the narrative structure model proposed by Labov and colleagues (Labov and Waletzky, I967) and is a compound of four dimensions: orientation, structural sequence, evaluative commitment, and integration. Each of these indicators is according to its presence in a five-point Likert scale (Gonçalves et al., 2002)

- Manual for Evaluation of Narrative Process and Complexity - this evaluation manual is inspired by the 'Narrative Process Coding Systems' proposed by Lynne Angus (Angus et al., I996). This system allows the evaluation of the complexity level of the narrative process by rating the diversity of the sensorial experience, complexity of subjective states (emotional and cognitive), and the diversity of meanings present in the narrative (Gonçalves et al., 200Ia), through a compound of four indicators: objectifying (sensorial complexity), emotional subjectifying (emotional complexity), cognitive subjectifying (cognitive complexity), and metaphorizing (metacognitive and meaning construction complexity)

- Manual for Evaluation of Narrative Content and Multiplicity - this manual was devised for the assessment of the diversity in narrative components as expressed in themes, events, scenarios and characters present in the narrative (Gonçalves et al., 200Ic). A narrative highly scored in this subdimension is a story in which several themes appear, and multiple characters interact in a great variety of settings within a complex and diversified net of events. On the contrary, a narrative with only one theme, only one character, in only one setting with a redundancy of events is, in at best, an expression of undifferentiated experience.

\section{Procedure}

Socio-demographic, diagnosis, clinical story, and consent forms were obtained from the participants, after explaining the goals of the research. Then, Wechsler Intelligence Scale-R and PPVT were administered to all groups. Finally, the narrative elicitation task was used. Narratives were transcribed and analysed in terms of narrative structural coherence, narrative process complexity, and narrative content diversity.

\section{Data analysis}

Taking into account the small number of participants, a descriptive analysis of the cases was performed.

\section{Results}

Full-scale IQ and composite measures of the Wechsler Intelligence Scale (VIQ and PIQ) were inferior in participants with WS, when compared with the other participants. However, individuals with WS scored higher on PPVT (Peabody 
Verbal Age: $\mathrm{M}=9 \cdot 05, \mathrm{SD}=2 \cdot 36)$ when compared with PWS $(\mathrm{M}=8 \cdot 45, \mathrm{SD}=0 \cdot 49)$ and particularly with individuals with $\mathrm{SMS}(\mathrm{M}=5 \cdot 05, \mathrm{SD}=0 \cdot 77)$.

In terms of narrative production, results are presented in two sections. First, global results for the narrative quality are analysed for the three genetic conditions. Then, each subdimension of narrative structure, process and content will be explored in detail.

\section{Global narrative quality}

Higher global scores in structural coherence and process complexity dimensions were observed in the two participants with SMS, while the lowest scores were obtained in individuals with PWS (Fig. I). However, when content diversity dimension was analysed, both PWS and WS individuals scored higher (see Appendix 2 for a narrative example).

\section{Narrative structural coherence}

Overall, individuals with SMS perform in the medium range in all structural subdimensions $(2 \cdot 5-3 \cdot 5)$, except for integration ability (Fig. 2), in which they scored less $(\mathrm{I} \cdot 5)$. Additionally, integration and orientation were subdimensions in which individuals with WS displayed low scores (2), in contrast to a moderate performance in structural and evaluative commitment subdimensions $(2 \cdot 5-3)$.
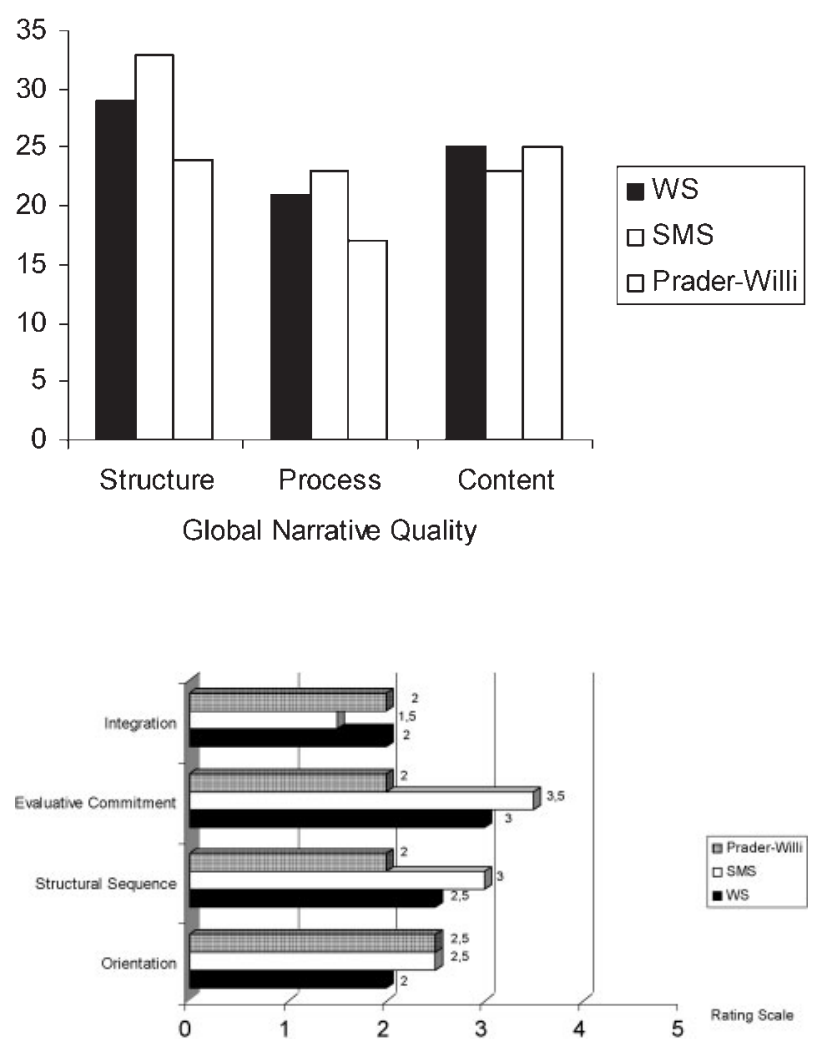

FIGURE 1 Global scores for narrative structure, process, and content in participants with WS, SMS, and PWS.

FIGURE 2 Scores for the subdimensions of narrative structure and coherence in participants with WS, SMS, and PWS. 

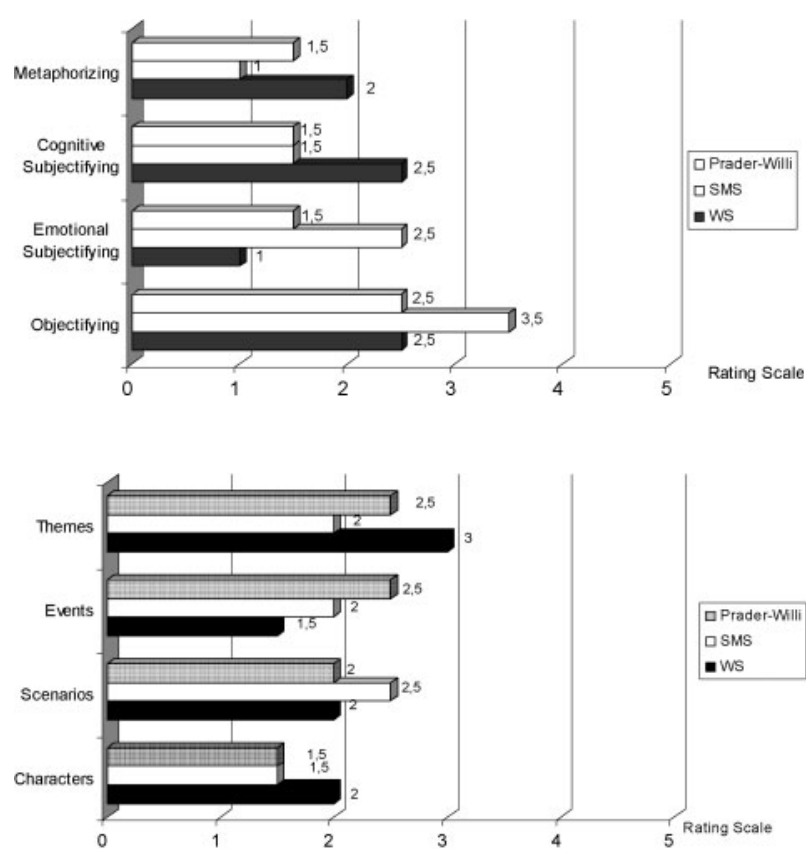

FIGURE 3 Scores for the subdimensions of narrative process and complexity in participants with WS, SMS, and PWS.
FIGURE 4 Scores for the subdimensions of Narrative Content and Diversity in participants with WS, SMS, and PWS.

Finally, individuals with PWS scored globally within the low range $(2-2 \cdot 5)$ in all subdimensions of narrative structural coherence.

\section{Narrative process complexity}

When narrative process complexity was analysed, a high variability between genetic conditions was found (Fig. 3). Participants with WS, SMS, and PWS scored in the low to average range interval $(\mathrm{I}-2 \cdot 5)$ in all subdimensions of narrative process and complexity, with an exception being observed for the ability to explore the sensorial multiplicity in the elaboration of personal experiences (Objectifying), whereas individuals with SMS displayed superior performance $(3 \cdot 5)$. Surprisingly, individuals with WS exhibited a very low performance in Emotional Subjectifying (I).

Also, scores in the subdimensions of narrative content diversity (Fig. 4) differed in all three groups. Thus, individuals with WS scored in the average range for diversity of themes (3), but worse in diversity of events $(\mathrm{I} \cdot 5)$. With respect to PWS and SMS, it was possible to observe a global low performance in all variables $(\mathrm{I} \cdot 5-2 \cdot 5)$, with individuals with SMS being relatively better than the other individuals in the ability to describe the places in which actions take place (Scenarios: $-2 \cdot 5)$.

\section{Discussion}

In this study, we compared the narrative production of three genetic disorders WS, SMS, and PWS, and results showed an interesting highly variable phenotype in the different subdimensions of the narrative structure, process, and content. 
Indeed, all individuals exhibited a global poor performance in the different subdimensions of narrative production, although with different patterns of performance.

When we analysed narrative structural coherence, some interesting results emerged. Within this dimension, we observed that the ability to integrate the elements of the narrative into a coherent story was more evident in individuals with PWS and WS. These data suggest that individuals with WS, despite having a poor narrative structural coherence, may be able to globally process the information and possibly integrate and relate it with the different elements of the visual story. This can be associated with their ability to process information and organize it in order to provide an integrated output both locally and configurationally, observable both in WS (Pani et al., I999; Farran, 2005) and PWS (Rosell-Raga, 2003).

Another interesting result was related to the evaluative commitment subdimension. It would be expected that, taking into account the WS spared socio-affective component of the narrative (Jones et al., 2000; Gonçalves et al., 2004; Garayzabal Heinze et al., 2007), individuals with WS would score better in evaluative commitment, with respect to the other participants. However, participants with SMS were those who displayed better scores in this subdimension. These data suggest that the use of audience hookers and engaging audience devices may be an overall feature of pro-social phenotypes, characterized by attractive and outgoing personalities, both commonalities of WS and SMS.

Globally, the results in narrative structure coherence suggest that SMS were able to maintain the basic sequence of the story, as they were capable of identifying the beginning, development and ending of a narrative. Individuals with WS were able to identify the beginning of a story and the possible end, but not the development of events that occur in the story. Finally, participants with PWS were able to identify only the beginning of the narrative.

With respect to the complexity of the narrative process, the ability to explore the diversity of the sensorial experience (objectivation) and emotional subjectifying seem to be relatively spared abilities in SMS. In an opposite way, the participants with WS had surprisingly low results in all measures of the narrative process, inclusively in the emotional subjectifying subdimension. These results are in contrast with previous studies, using the same narrative elicitation task, and evidencing that individuals with WS were capable of attributing more emotional states to story characters (Losh et al., 200I). However, our result has been shown in other studies using bigger samples (Gonçalves et al., 2010), and are possibly related to evidence reporting an impairment in emotion recognition abilities in WS (Plesa-Skwerer et al., 2006).

Finally, when the diversity of narrative content is analysed, we observed a global superior performance of participants with WS in all measures, with an exception for scenario score. This can possibly be related with the extreme importance given to characters within the narrative by individuals with WS. Again, the socioaffective component of the WS narrative emerges, relying upon the introduction of new characters to enrich the story (Jones et al., 2000; Gonçalves et al., 2004; Reilly et al., 2004; Garayzabal Heinze et al., 2007). In a different way, individuals with 
PWS apparently take more advantage over their relatively good long-term memory, expressive vocabulary, and global processing abilities (Rosell-Raga, 2003), which is evident in their performance in themes and events. Also, they exhibit lower scores in character subdimension, possibly in accordance with their behaviour problems, namely, aggressiveness, stubbornness, emotional lability, and difficulties in adopting the other point of view (Dykens et al., I999). Finally, relative strengths of individuals with SMS in perceptual closure, discrimination figure/frame, and space-perception relations (Dykens et al., I997; Udwin et al., 200I), abilities required to provide a good description of the places in which actions occur, may facilitate their performance on scenario subdimension.

Despite the high variability of all three genetic syndromes in all the subdimensions, it was possible to observe that WS and SMS exhibit relatively better performances in subdimensions that appeal to a more social component of the narrative, which is consistent with their typical social skills (Sarimski, 2004; Smith et al., I998), namely, their behavioural profile oriented towards social contact and interactions (Smith et al., I998; Jones et al., 2000; Gonçalves et al., 2004; Reilly et al., 2004; Sarimski, 2004). However, this pro-social profile was not so clear in PWS, suggesting that their conflictual and social withdrawal personality contribute to a narrative that is oriented towards non-social elements (objectifying), lacking diversity of themes and characters, in the context of scenario diversity.

\section{Conclusions and Practical Application}

This preliminary study is the first comparing patients with SMS, WS, and PWS in a narrative production task. These are neurodevelopmental microdeletion genetic based disorders, described in the literature as having general intellectual disability with relative good language skills. Our hypothesis was that narrative production was impaired in the three syndromes, taking into account the complex multimodal aspects of a narrative as well as the stages of narrative development.

However, the current results should be analysed only as case studies and should be interpreted cautiously, given the small number of participants in the three genetic conditions. Indeed, future studies should explore some of these hypotheses in the context of a more extended population and, if confirmed, important clinical implications could be drawn.

Narrative analysis provides a useful framework for understanding multiple dimensions of cognitive, emotional, and social processing styles, namely, by requiring several cognitive abilities, including attention skills (selection, coding, and interpretation of relevant information) necessary for organization the structure of the story; generation of inferences (e.g. cognitive, emotional) that allow the appropriate interpretation of the information; and finally, the efficient use of recovery skills. In addition, narrative production is an important source of information on social functioning and children language because it requires the ability to take into account the information requirements of the listener and to use linguistic forms to fulfil the communicative purposes. Thus, analysis of narrative production abilities must necessarily have immediate implications for intervention. 
Indeed, reports on development of narrative skills suggest that at 3 years of age, children have a primitive narrative with a main character and events related to this character logically unorganized; at 5 years of age, with the improvement of language structure, there is a logical sequence of events and during adolescence, they are able to use language structures fluently in a flexible and organized way (Hedberg and Stoel-Gammon, I986). Thus, in this study, we did not find evidence for the existence of a proficient narrative profile in the patients under study. Indeed, we verified low global narrative quality, displaying highly variable scores in different subdimensions of narrative structure, process, and content among the three genetic syndromes.

The results obtained in this study show that speech intervention directed specifically to narrative production could be very valuable. We observed that these participants do not manage well with the basic formal structure of a story: the beginning, the development, and the ending. Although some of these factors are mentioned, they are confusing, incomplete, or inappropriate, poorly organized and less cohesive. Also, the absence of a clear target was observed in the majority of the narratives. This involves the management of internal states or intentions of the characters that justify their actions. That is a reason why the ends of their narratives are so rough and the establishment of cause-effect relationships is rarely observed. The content organization was also very different from those observed in other syndromes, thus, an intervention in formal structure, which was focused on the use of formal categories and the proper use of discursive markers, could be a helpful way for them to deal with language, social functioning, and cognitive approaches to organize their world. We suggest that through an intervention, which takes into account different narrative production deficits, the participants could increase the amount of full episodes described within the narrative (e.g. by incorporating obstacles and different outcomes in their stories) and be able to manage both macro- and microstructure elements of the narrative. Finally, guiding speech and educational therapy according to these specific narrative profiles, we could therefore potentiate the development of other skills, since this type of discourse involves not only the linguistic skills but also cognitive processing and social abilities.

\section{Acknowledgements}

We want to thank the Spanish Williams Syndrome Association, the Spanish SmithMagenis Syndrome Association, and the Madrid Prader-Willi Syndrome Association. This research was supported by the grants FEDER - I Convocatória Inocente Inocente 2009.

\section{References}

Akefeldt, A., Akefeldt, B. and Gillberg, C. I997. Voice, speech and language characteristics of children with Prader-Willi syndrome, J. Intellect. Disabil. Res., 4I, (Pt 4), 302-3 I I.

Angus, L. E., Hardtke, K. and Levitt, H. I996. A rating manual for the Narrative Process Coding System; North York, Ont, York University. 
Annaz, D., Karmiloff-Smith, A., Johnson, M. H. and Thomas, M. S. 2009. A cross-syndrome study of the development of holistic face recognition in children with autism, Down syndrome, and Williams syndrome, J. xp. Child Psychol., I02, (4), 456-486.

Artigas-Pallarés, J. 2002. Fenotipos Conductuales, Rev. Neurol, 34, (Suppl. I), S38-S48.

Bellugi, U., Bihrle, A., Jernigan, T., Trauner, D. and Doherty, S. I990. Neuropsychological, neurological, and neuroanatomical profile of Williams syndrome,Am. J. Med. Genet. 6, II 5-I 25.

Bellugi, U., Lichtenberger, L., Jones, W., Lai, Z. and St George, M. 2000. The neurocognitive profile of Williams syndrome: a complex pattern of strengths and weaknesses, J. Cogn. Neurosci, I2, (Suppl. I)729.

Bellugi, U., Lichtenberger, L., Mills, D., Galaburda, A. and Korenberg, J. R. I999. Bridging cognition, the brain and molecular genetics: evidence from Williams syndrome, Trends Neurosci., 22, (5), I97207.

Bellugi, U., Wang, P. P. and Jernigan, T. J. I994. Williams syndrome: an unusual neuropsychological profile, in Atypical cognitive deficits in developmental disorders: implications for brain function, (ed. S. B. J. Grafman); Hillsdale, NJ, Lawrence Erlbaum Associates, 23-56.

Brock, J. 2007. Language abilities in Williams syndrome: a critical review, Dev. sychopathol., I9, (I), 97I 27.

Chiang, M. C., Reiss, A. L., Lee, A. D., Bellugi, U., Galaburda, A. M., Korenberg, J. R., Mills, D. L., Toga, A. W. and Thompson, P. M. 2007.3D pattern of brain abnormalities in Williams syndrome visualized using tensor-based morphometry, Neuroimage, 36, (4), I096-I I09.

Curfs, L. M., Verhulst, F. C. and Fryns, J. P. I99I. Behavioral and emotional problems in youngsters with Prader-Willi syndrome, Genet Couns, 2, (I), 33-4I.

Defloor, T., Borsel, J. V., Curfs, L. (2000). Speech fluency in Prader-Willi syndrome. Journal of Fluency Disorders, 25, 2, 85-98.

Donaldson, M. D., Chu, C. E., Cooke, A., Wilson, A., Greene, S. A. and Stephenson, J. B. I994. The PraderWilli syndrome, Arch. Dis. Child, 70, (I), 58-63.

Dunn, L. M. and Dunn, L. M. I98I. Peabody Picture Vocabulary Test-Revised; Circle Pines, MN, American Guidance Services.

Dykens, E. M., Cassidy, S. B. and King, B. H. I999. Maladaptive behavior differences in Prader-Willi syndrome due to paternal deletion versus maternal uniparental disomy, Am. J. Ment. Retard., I04, (I), 6777.

Dykens, E. M., Finucane, B. M. and Gayley, C. I997. Brief report: cognitive and behavioral profiles in persons with Smith-Magenis syndrome, J. Autism Dev. Disord., 27, (2), 203-2 I I.

Dykens, E. M. and Smith, A. C. I998. Distinctiveness and correlates of maladaptive behaviour in children and adolescents with Smith-Magenis syndrome, J. Intellect. Disabil. Res., 42, (Pt 6)48I-489.

Elsea, S. H. and Girirajan, S. 2008. Smith-Magenis syndrome, Eur. J. Hum. Genet., 16, (4), 4I2-42I.

Farran, E. K. 2005. Perceptual grouping ability in Williams syndrome: evidence for deviant patterns of performance, Neuropsychologia, 43, (5), 8 I 5-822.

Feinstein, C. and Singh, S. 2007. Social phenotypes in neurogenetic syndromes, Child Adolesc. Psychiatr. Clin. N. Am., I6, (3), 63 I-647.

Gagliardi, C., Frigerio, E., Burt, D. M., Cazzaniga, I., Perrett, D. I. and Borgatti, R. 2003. Facial expression recognition in Williams syndrome, Neuropsychologia, 4I, (6), 733-738.

Garayzabal Heinze, E., Prieto, M.F., Sampaio, A. and Goncalves, O. 2007. [Cross-linguistic assessment of verbal production from a narrative task in Williams syndrome], Psicothema, I9, (3), 428-434.

Gonçalves, O. F., Henriques, M. R., Alves, A. and Rocha, C. 200Ia. Narrative process and complexity evaluation manual; Braga, Universidade do Minho.

Gonçalves, O. F., Henriques, M. R., Alves, A. and Soares, L. 2002. Analyzing structure, process and content in narratives of patients diagnosed with agoraphobia, Int. J. Clin. Health Psychol., 2, (3), 389-406.

Gonçalves, O. F., Henriques, M. R. and Cardoso, G. 200Ib. Narrative structure and coherence evaluation manual; Braga, Universidade do Minho.

Gonçalves, O. F., Henriques, M. R., Soares, L. and Monteiro, A. 200Ic. Narrative content and multiplicity evaluation manual; Braga, Universidade do Minho. 
Gonçalves, O. F., Pérez, A., Henriques, M., Prieto, M., Lima, M., Siebert, M. and Sousa, N. 2004. Funcionamento Cognitivo e Produção Narrativa no Síndrome de Williams: Congruência ou Dissociação Neurocognitiva?, Int. J. Clin. Health Psychol., 4, 623-638.

Gonçalves, O. F., Pinheiro, A. P., Sampaio, S., Sousa, N., Fernandez, M. and Henriques, M. 2010. The narrative profile in Williams syndrome: there is more to storytelling than just telling a story, Br. J. Dev. Disabil., 56, (2), 89-IIо.

Gonçalves, O. F., Pinheiro, A. P., Sampaio, S., Sousa, N., Férnandez, M. and Henriques, M. 20 II. Autobiographical narratives in williams syndrome: structural, process and content dimensions, J. Dev. Phys. Disabil., 23, 289-302.

Greenberg, F., Guzzetta, V., Montes de Oca-Luna, R., Magenis, R. E., Smith, A. C., Richter, S. F., Kondo, I., Dobyns, W. B., Patel, P. I. and Lupski, J. R. I99I. Molecular analysis of the Smith-Magenis syndrome: a possible contiguous-gene syndrome associated with $\operatorname{del}(\mathrm{I} 7)(\mathrm{pII} \cdot 2)$, Am. J. Hum. Genet., 49, (6), I207I 2 I 8.

Greenberg, F., Lewis, R.A., Potocki, L., Glaze, D., Parke, J., Killian, J., Murphy, M. A., Williamson, D., Brown, F., Dutton, R., McCluggage, C., Friedman, E., Sulek, M. and Lupski, J. R. I996. Multi-disciplinary clinical study of Smith-Magenis syndrome (deletion I7pi r.2), Am. J. Med. Genet., 62, (3), 247-254.

Greer, M. K., Brown, F. R., 3rd, Pai, G. S., Choudry, S. H. and Klein, A. J. I997. Cognitive, adaptive, and behavioral characteristics of Williams syndrome, Am. J. Med. Genet., 74, (5), 52I-525.

Gropman, A. L., Duncan, W. C. and Smith, A. C. 2006. Neurologic and developmental features of the SmithMagenis syndrome (del I7pi I.2), Pediatr. Neurol., 34, (5), 337-350.

Hedberg, N. and Stoel-Gammon, C. 1986. Narrative analysis: clinical procedures, Top. Lang. Disord., 7, $58-$ 69.

Henriques, M., Pérez, A., Prieto, M., Reis Lima, M. and Gonçalves, O. 2004. Funcionamento cognitivo e produção narrativa no síndrome de Williams: congruência ou dissociação neurocognitiva?, Int. J. Clin. Health Psychol., 4, (3), 623.

Jones, W., Bellugi, U., Lai, Z., Chiles, M., Reilly, J. and Adolphs, R. 2000. Hipersociability in Williams syndrome, J. Cogn. Neurosci., I2, 30-46.

Kleppe, S. A., Katayama, K. M., Shipley, K. G. and Foushee, D. R. I990. The speech and language characteristics of children with Prader-Willi syndrome, J. Speech Hear. Disord., 55, (2), 300-309.

Labov, W. and Waletzky, J. I967. Narrative analysis: oral versions of personal experience, in Proc. I996 Annual Spring Meet. of the American Ethnological Society: Essays on the verbal and visual arts, (ed. J. Helm); Seattle: WA, University of Washington Press, I 2-45.

Lewis, B. 2006. Speech and language disorders associated with PWS, in Management of Prader-Willi syndrome; New York, Springer, 272-283.

Losh, M., Bellugi, U. and Anderson, J. 200I. Narrative as a social engagement tool: the excessive use of evaluation in narratives from children with Williams syndrome, Narrat. Inq., Io, (2), 265-290.

Mayer, M. I969. Frog, where are you?; New York, Dial Press.

Mercuri, E., Atkinson, J., Braddick, O., Rutherford, M. A., Cowan, F. M., Counsell, S. J., Dubowitz, L. M. and Bydder, G. I997. Chiari I malformation in asymptomatic young children with Williams syndrome: clinical and MRI study, Eur. J. Paediatr. Neurol., I, (5-6), I77-I8 I.

Metcalfe, K. I999. Williams syndrome: an update on clinical and molecular aspects, Arch. Dis. Child, 8I, (3), I $98-200$.

Pani, J. R., Mervis, C. B. and Robinson, B. F. I999. Global spatial organization by individuals with Williams syndrome, Psychol. Sci., Io, 453-458.

Plesa-Skwerer, D., Faja, S., Schofield, C., Verbalis, A. and Tager-Flusberg, H. 2006. Perceiving facial and vocal expressions of emotion in individuals with Williams syndrome, Am. Ment. Retard., III, (I), I 5-26.

Potocki, L., Glaze, D., Tan, D. X., Park, S. S., Kashork, C. D., Shaffer, L. G., Reiter, R. J. and Lupski, J. R. 2000. Circadian rhythm abnormalities of melatonin in Smith-Magenis syndrome, J. ed. Genet., 37, (6), $428-433$.

Prader, A., Labhart, A.and Willi, H. I956. Ein Syndrome von Adipositas, Kleinwuchs, Kriptorchismus und Oligofrenie nach myotonieartigem Zustandim Neugeborenenalter, Schweiz. ed. Wochenschr., 86, I260I26I. 
Reilly, J., Losh, M., Bellugi, U. and Wulfeck, B. 2004. 'Frog, where are you?' Narratives in children with specific language impairment, early focal brain injury, and Williams syndrome, Brain Lang., 88, (2), 229-247.

Rosell-Raga, L. 2003. Fenotipos conductuales en el síndrome de Prader Willi, Rev. Neurol, 36, (Suppl. I) I $_{53}$-S 57 .

Sarimski, K. 2004. Communicative competence and behavioural phenotype in children with Smith-Magenis syndrome, Genet. ouns., I5, (3), 347-355.

Schulze, A., Hansen, C., Baekgaard, P., Blichfeldt, S., Petersen, M. B., Tommerup, N. and Brøndum-Nielsen, K. I997. Clinical features and molecular genetic analysis of a boy with Prader-Willi syndrome caused by an imprinting defect, Acta Paediatr., 86, (8), 906-9 Iо.

Semel, S. R. and Rosner, E. 2003. Understanding Williams syndrome: behavioral patterns and interventions; Mahwah, NJ, Lawrence Erlbaum Associates.

Smith, A. C., Dykens, E. and Greenberg, F. I998. Behavioral phenotype of Smith-Magenis syndrome (del I7pi г 2), Am. . Med. Genet., 8I, (2), I79-I 85 .

Smith, A. C., McGavran, L., Robinson, J., Waldstein, G., Macfarlane, J., Zonona, J., Reiss, J., Lahr, M., Allen, L. and Magenis, E. I986. Interstitial deletion of (I7)(pII·2pI I·2) in nine patients, Am. . Med. Genet., 24, (3), 393-4I4.

Stevens, T. and Karmiloff-Smith, A. I997. Word learning in a special population: do individuals with Williams syndrome obey lexical constraints?, J. Child Lang., 24, (3), 737-765.

Stojanovik, V. 2006. Social interaction deficits and conversational inadequacy in Williams syndrome, J. eurolinguistics, I9, I 57-I73.

Stojanovika, V., Perkinsb, M.and Howardb, S. 2004. Williams syndrome and specific language impairment do not support claims for developmental double dissociations and innate modularity, J. eurolinguistics, I7, 403-424.

Stromme, P., Bjornstad, P.G. and Ramstad, K. 2002. Prevalence estimation of Williams syndrome, J. hild Neurol., I7, (4), 269-27I.

Thomas, M. S. C., Dockrell, J., Messer, D., Parmigiani, C., Ansari, D. and Karmiloff-Smith, A. 2006. Speeded naming, frequency and the development of the lexicon in Williams syndrome, Lang. ogn. Processes, 2I, 72I-759.

Udwin, O., Webber, C.and Horn, I. 200I. Abilities and attainment in Smith-Magenis syndrome, Dev. ed. Child Neurol., 43, (I 2), 823-828.

Vogels, A., de Hert, M., Descheemaeker, M. J., Govers, V., Devriendt, K., Legius, E., Prinzie, P. and Fryns, J. P. 2004. Psychotic disorders in Prader-Willi syndrome, Am. . Med. Genet. A, I27A, (3), 238-243.

Vogels, A. and Fryns, J. P. 2004. Age at diagnosis, body mass index and physical morbidity in children and adults with the Prader-Willi syndrome, Genet. ouns., I5, (4), 397-404.

Vogels, A., van den Ende, J., Keymolen, K., Mortier, G., Devriendt, K., Legius, E. and Fryns, J. P. 2004. Minimum prevalence, birth incidence and cause of death for Prader-Willi syndrome in Flanders, Eur. Hum. Genet., I2, (3), 238-240.

Wechsler, D. I974. Wechsler Intelligence Scale for Children-Revised; New York, Psychological Corporation. Wigren, M. and Hansen, S. 2005. ADHD symptoms and insistence on sameness in Prader-Willi syndrome, J. Intellect. Disabil. Res, 49, (Pt 6), 449-456.

\section{Notes on contributors}

Correspondence to: Elena Garayzábal-Heinze, Universidad Autœnoma de Madrid, Departamento de Lingüística, Facultad de Filosofía y Letras, 28049 Madrid, Spain. Telephone: 0034 9I4974472. Email: elena.garayzabal@uam.es 


\section{Appendix I}

\section{Subdimensions of narrative structure}

\begin{tabular}{|c|c|c|}
\hline \multicolumn{3}{|l|}{ I. Structural coherence } \\
\hline \multirow[t]{5}{*}{ a) Orientation } & Does the narrative make reference to: & What is the context of the narrative? \\
\hline & - characters? & \\
\hline & $\begin{array}{l}\text { - the social/spatial/temporal/personal context } \\
\text { where behaviours take place? }\end{array}$ & \\
\hline & $\begin{array}{l}\text { - past relevant events that have contributed for } \\
\text { the occurrence of current behaviours? }\end{array}$ & \\
\hline & $\begin{array}{l}\text { - relevant events that have occurred } \\
\text { after the central event? }\end{array}$ & \\
\hline \multirow[t]{5}{*}{ b) Structural coherence } & Does the narrative make reference to: & And then, what happened? \\
\hline & - an initial event? & \\
\hline & - an internal response to the event? & \\
\hline & - an action? & \\
\hline & - the associated consequences? & \\
\hline \multirow[t]{3}{*}{ c) Evaluative commitment } & Does the narrative make reference to: & Why have the narrative been told? \\
\hline & - the emotional states of the narrator? & \\
\hline & - the extent of his commitment with the narrative? & \\
\hline d) Integration & $\begin{array}{l}\text { Are the elements of narrative described in } \\
\text { an integrated/coherent manner? }\end{array}$ & Is the guideline of discourse clear? \\
\hline
\end{tabular}

\section{Subdimensions of narrative process}

II. Narrative process complexity

a) Objectifying Does the narrative make reference to:

What are the sensorial experiences

of the characters?

- sensorial elements related with the episode's description? In what extent?

b) Emotional subjectifying Does the narrative make reference to:

What are the emotional experiences of the characters?

- emotional states related with specific events? In what extent?

c) Cognitive subjectifying Does the narrative make reference to:

What are the cognitive experiences of the characters?

- cognitions, ideas, thoughts, and plans of the characters referred? In what extent?

d) Metaphorizying Does the narrative make reference to: How does the narrator make sense of the events described?

- the meanings constructed by the narrator, in order to make sense of the episodes described? 


\section{Subdimensions of narrative content}

\begin{tabular}{|c|c|c|}
\hline \multicolumn{3}{|c|}{ III. Narrative content diversity } \\
\hline a) Themes & - How many themes are introduced in the narrative? & $\begin{array}{l}\text { What are the thematic contexts introduced } \\
\text { in the narrative? }\end{array}$ \\
\hline b) Events & - How many action sequences are described? & And then, what happened? \\
\hline c) Scenarios & $\begin{array}{l}\text { - Does the narrative make reference to the environment } \\
\text { that surrounds the events described? }\end{array}$ & What is the context where action takes place? \\
\hline d) Characters & $\begin{array}{l}\text { - How many (real or imagined) characters are } \\
\text { introduced in the narrative? }\end{array}$ & Who are the agents of the actions described? \\
\hline
\end{tabular}

\section{Appendix 2}

\begin{tabular}{|c|c|c|}
\hline $\begin{array}{l}\text { Narrative from MM } \\
\text { (Williams syndrome) }\end{array}$ & $\begin{array}{l}\text { Narrative from MG } \\
\text { (Smith-Magenis syndrome) }\end{array}$ & $\begin{array}{l}\text { Narrative from IM } \\
\text { (Prader-Willi syndrome) }\end{array}$ \\
\hline $\begin{array}{l}\text { Había una vez un niño y un perro } \\
\text { que habian conseguido una ranita. }\end{array}$ & $\begin{array}{l}\text { Pues está un niño, un perro y miran la } \\
\text { rana en el cuarto. Luego se van a } \\
\text { dormir y la rana se va. Ya es de día y el } \\
\text { perro y el niño no ven a la rana. Se ha } \\
\text { ido. Luego buscan y buscan y no la } \\
\text { encuentran. El perro mete la cabeza y } \\
\text { luego no puede sacarla. Se cae, el niño } \\
\text { se enfada y el perro le chupa. }\end{array}$ & $\begin{array}{l}\text { Un niño que está en casa con un perro y } \\
\text { luego se acuesta; luego por la mañana pone } \\
\text { sus zapatillas, mira por la ventana a ver qué } \\
\text { día hace. Va al bosque y está hablando a ver } \\
\text { si había algo por ahí. Luego, pues ve un } \\
\text { agujero y luego, bueno, ve un ratoncito. }\end{array}$ \\
\hline
\end{tabular}

Aquella misma noche el niño olvidó Grita a la rana y el perro ahi sentado. Pues el perro está jugando ahi con un árbol tapar la tapa para que la rana no se Luego ven un agujero y llama. El perro y el niño está subido a un árbol. Se asusta escapara. se sube al árbol para ver qué es eso con un búho, se da en la cabeza. (señala el avispero). Sale un animal y el niño se rasca la nariz, parece enfadado. El perro tira eso (señala avispero) y salen las abejas.

Pero al día siguiente ocurrió algo inesperado. jla rana se había escapado!

El niño y el perro desesperados empezaron a buscar, pero no la encontraron.

Pero por la causa que se había escapado, la ventana estaba abierta. Ahora se sube a un árbol y grita. Sale un pájaro y se cae; se puede hacer daño ¿verdad?. El perro está corriendo, le van a picar ijo!

Entonces el niño llama y se agarra para no caerse. Luego le coge el ciervo y el niño se asusta. Se caen por el barranco, también el perro. Aquí es donde viven las ranas (señala el nenúfar). Le dice al perro que se calle y se van a un tronco que está en el agua. Miran al otro lado.

Hay dos ranitas y luego hay más. Coge una ranita y se despide.
Está llamando al perro. Se sube a la roca y un ciervo. El ciervo le tira al agua con el perro. Se moja, se ríe el ciervo. Y luego se queda ahi pensativo. Y luego le dice al perro que se calle. Mira por el tronco, se tumba el niño y miran a las dos ranas.

Está para tirar una rana por ahi y luego una familia de ranas.

,




\begin{tabular}{|c|c|c|}
\hline $\begin{array}{l}\text { Narrative from MM } \\
\text { (Williams syndrome) }\end{array}$ & $\begin{array}{l}\text { Narrative from MG } \\
\text { (Smith-Magenis syndrome) }\end{array}$ & $\begin{array}{l}\text { Narrative from IM } \\
\text { (Prader-Willi syndrome) }\end{array}$ \\
\hline \multicolumn{3}{|l|}{ Dijeron: ¡Ranita! ¿Dónde estás? } \\
\hline \multicolumn{3}{|c|}{$\begin{array}{l}\text { Pero lo que no sabian era que el } \\
\text { perro estaba provocando a unas } \\
\text { avispas y quisieron perseguirlo. }\end{array}$} \\
\hline \multicolumn{3}{|c|}{$\begin{array}{l}\text { El avispero se fue al garete y se vino } \\
\text { abajo. }\end{array}$} \\
\hline \multicolumn{3}{|c|}{$\begin{array}{l}\text { El avispero se fue tras el perro. El } \\
\text { perro estaba corriendo detrás. }\end{array}$} \\
\hline \multicolumn{3}{|l|}{$\begin{array}{l}\text { Aparece un búho de repente. } \\
\text { Creyeron que eran unas ranas. }\end{array}$} \\
\hline \multicolumn{3}{|c|}{$\begin{array}{l}\text { Pero no se esperaba una sorpresa. } \\
\text { Eran unos cuernos jun ciervo! }\end{array}$} \\
\hline \multicolumn{3}{|c|}{ El ciervo se detuvo y los tiró al río. } \\
\hline \multicolumn{3}{|c|}{$\begin{array}{l}\text { El ciervo miraba cómo se } \\
\text { zambullían. El perro y el niño } \\
\text { encontraron un árbol. }\end{array}$} \\
\hline \multicolumn{3}{|c|}{$\begin{array}{l}\text { Dijo jshhhh! jVamos a mirar, a lo } \\
\text { mejor hay una rana! }\end{array}$} \\
\hline \multicolumn{3}{|c|}{$\begin{array}{l}\text { Encontraron la rana y una ranita y } \\
\text { unos ranitos. }\end{array}$} \\
\hline \multicolumn{3}{|c|}{$\begin{array}{l}\text { ¡Nos llevamos a una ranita! Colorín } \\
\text { colorado, este cuento se ha } \\
\text { acabado. }\end{array}$} \\
\hline \multicolumn{3}{|l|}{ Structure and coherence } \\
\hline Orientation -3 & Orientation 3 & Orientation 2 \\
\hline Structural sequence -3 & Structural sequence 3 & Structural sequence 2 \\
\hline Evaluative commitment -3 & Evaluative commitment 4 & Evaluative commitment 2 \\
\hline Integration -3 & Integration 3 & Integration 3 \\
\hline \multicolumn{3}{|l|}{ Process and complexity } \\
\hline Objectifying -3 & Objectifying 4 & Objectifying 3 \\
\hline Emotional subjectifying - 1 & Emotional subjectifying 3 & Emotional subjectifying 2 \\
\hline Cognitive subjectifying -3 & Cognitive subjectifying 1 & Cognitive subjectifying 1 \\
\hline Metaphorizing -3 & Metaphorizing 1 & Metaphorizing 2 \\
\hline \multicolumn{3}{|l|}{ Content and multiplicity } \\
\hline Characters -3 & Characters 3 & Characters 3 \\
\hline Scenarios - 2 & Scenarios 1 & Scenarios 3 \\
\hline Events - 2 & Events 3 & Events 2 \\
\hline Themes -2 & Themes 1 & Themes 1 \\
\hline
\end{tabular}

